\title{
CHARACTERISTICS OF VIRAL INFECTION DEVELOPMENT CAUSED BY POTATO VIRUS M UNDER THE IMPACT OF BIOPREPARATIONS ON POTATO PLANTS
}

\author{
I. H. Budzanivska ${ }^{1}$, T. O. Bova ${ }^{2}$, O. O. Kucheriavenko ${ }^{2}$, O. V. Pyrih $^{2}$, \\ O. O. Dmytruk ${ }^{2}$ \\ ${ }^{1}$ Taras Shevchenko National University of Kyiv, ESC «Institute of Biology», \\ 2, Hlushkova Avenue, Kyiv City, 03187, Ukraine; e-mail: decanat_bf@univ.kiev.ua
}

Viral diseases are the cause of potato varieties degeneration, and they are the subject of close attention for potato breeders in many countries [1]. The reproduction of the virus in the plant causes significant physiological changes and functional disorders (metabolic imbalances of protein, nucleic acids, carbohydrates, photosynthesis, respiration, transpiration and water exchange, etc.) [2].

Potato virus M (PVM, Potato virus M, Carlavirus genus, Betaflexiviridae family) is one of the most common pathogens of potato in all areas of cultivation. Yield losses from $\mathrm{M}$-viral infection can reach $41 \%$. Long-term data of the virology laboratory staff of the Institute of Agricultural Microbiology and Agroindustrial Manufacture of NAAS (IAMAM NAAS) testify that PVM is manifested as in monoinfection so in combination with other mosaic viruses. In addition, in $20-70 \%$ cases asymptomatic viral disease was detected. That is, even at the stage of growing of seeding sets the preconditions for economic loss in potato farming are formed $[3 ; 4]$. Therefore, finding the ways to reduce the loss from viral infections in potato crops is urgent nowadays.

The use of physiologically active substances that can stimulate natural defence mechanisms of plants is considered as a promising strategy in protecting against viral infections. Microbial preparations designed to improve nitrogen and phosphorus nutrition of plants distinguish with comprehensive positive impact on plants and safety for the environment and are one of the components of modern technologies of crops planting [5].

It should be noted that among the crops for which bacterial preparations were developed potato is somewhat aloof. The studies on potato inoculation are not as systematic and large-scale, as for many other crops, in Ukraine this item is also neglected [6].

Potato belongs to the crops with very poorly developed root system [6;7]. This gives reason to state that bacterization can play a special role in the technology of cultivation of this crop, since influencing the course of microbiological processes in the rhizosphere of plants their provision with nutrition elements can be improved, which, in turn, will stimulate positive changes in the growth and development of plants, yield formation and also provide improvement in the quality of obtained products [7].

In this context, the goal of this work was to study the characteristics of viral infection development caused by Potato virus $M$ under the impact of biopreparations on potato plants.

Materials and methods. The studies used a collection strain of PVM, which was isolated from potato plants of Nahoroda (Award) variety in the virology laboratory of IAMAM NAAS. The accumulation of the virus was carried out on Lycopersicon esculentum Mill. plants that were infected in the phase of 3-4 true leaves by mechanical inoculation [8; 9]. 21 days after infecting tomato plants were tested for the presence of PVM through the methods of electron microscopy [10] and polymerase chain reaction (PCR) [11].

Potato plants in vitro of Zhukovskyi early variety were used in the study, and they were planted in sterile soil. Soil moisture was maintained at $60 \%$ from full capacity during the growing season.

The treatment of potato plant roots was done in the day of planting. Root system was soaked Biogran and Bactopaslen at the rate of 1:10 and 1:100 respectively. Reference samples were treated with water. Repetition of the experiment - 15-time. 
14 days after planting of meristem potato into the soil part of the plants was infected with Potato virus $M$. The presence of virus in the experimental samples of potato plants was controlled on the $21^{\text {st }}$ day after the lesion with PVM by the use of electron microscopy [10] and enzyme immunoassay (EIA) [12]. Healthy tobacco plants (for negative control) and plants with PVM (for positive control) were used as the control.

The definition RNAase activity was performed on the $22^{\text {nd }}$ day after the lesion by A. K. Chakravorty method modified by Yu. I. Vlasov [13].

Sample weight of $1 \mathrm{~kg}$ of fresh plant material was triturated with $15 \mathrm{ml}$ of $0.06 \mathrm{M}$ phosphate buffer, $\mathrm{pH}$ 6.7. The trituration was performed on ice using silica sand. Then plant mass was pressed through 2 layers of gauze. The resulting extract was centrifuged at $10,000 \mathrm{~g}$ for $25 \mathrm{~min}$. The precipitate was discarded, and the supernatant was immediately acidified with $1 \mathrm{~N}$ hydrochloric acid to $\mathrm{pH} 5.0$ and left overnight at the temperature of $0^{\circ} \mathrm{C}$. Sediment dropped which were released by centrifugation at $4000 \mathrm{~g}$ for $25 \mathrm{~min}$, and the clear solution was used to determine the activity of RNAase. For this enzyme extract was adjusted to $20 \mathrm{ml}$ of phosphate buffer.

The studied sample that consisted of $0.7 \mathrm{ml}$ of enzyme extract, $1 \mathrm{ml}$ of phosphate buffer $\mathrm{pH} 5.0$ and $0.3 \mathrm{ml}$ of substrate (standard solution - yeast RNAase, $10 \mathrm{mg} / \mathrm{ml}$ ) was incubated in centrifuge tubes in the incubator at the temperature of $37^{\circ} \mathrm{C}$ during $75 \mathrm{~min}$. The procedure of making the reaction mixture was carried out in an ice bath. After the incubation $2 \mathrm{ml}$ of precipitator (mixture of $50 \mathrm{ml} 96 \%$ ethanol with $1.7 \mathrm{ml} 57 \% \mathrm{NClO}_{4}$ ) were added to the reaction mixture. This operation was also performed on ice. Reference samples were prepared to each studied sample. In reference samples the precipitator was added before the enzyme extract to stop the reaction.

The samples were immediately transferred on the ice bath after the incubation and kept in the cold for 2 hours to complete precipitation. Then centrifugation was performed at $3000 \mathrm{~g}$ for $30 \mathrm{~min}$. The resulting supernatant was adjusted to $10 \mathrm{ml}$ of phosphate buffer and spectrophotometered at $260 \mathrm{~nm}$.

So, biological preparations Biogran and Bactopaslen improved the physiological state of the potato plants of Zhukovskyi early variety at artificial plants infection with PVM. The use of biopreparations ensured development of higher infected plants compared to control by $6.0-15.5 \%$; total chlorophyll content - by $14.0 \%$ and $3.3 \%$ respectively. At the action of biopreparations the decrease of Potato virus $M$ concentration in plants was noted, and, consequently, the decrease activity of ribonuclease. 